\title{
2018 Railroad Tie Survey
}

\author{
Stephen T. Smith* \\ Stephen Smith Consulting, Helena, MT, USA \\ Email: stephen@stephensmithconsulting.com
}

How to cite this paper: Smith, S.T. (2019) 2018 Railroad Tie Survey. Journal of Transportation Technologies, 9, 276-286. https://doi.org/10.4236/jtts.2019.93017

Received: April 10, 2019

Accepted: May 18, 2019

Published: May 21, 2019

Copyright $\odot 2019$ by author(s) and Scientific Research Publishing Inc. This work is licensed under the Creative Commons Attribution International License (CC BY 4.0).

http://creativecommons.org/licenses/by/4.0/

\begin{abstract}
This article reports results of a survey of railroad tie management conducted by the Association of American Railroads (AAR) reflecting 2017 practices. Similar surveys were previously conducted for 2013 and 2008 practices. North American railroads purchase approximately 23 million new wood crossties annually. Most ties are used to replace worn ties. Through this survey, the AAR seeks to provide clarity to its member railroads, the regulators, and other interested parties, regarding how the railroads' tie purchase preferences and used tie management choices have been changing in response to changing technologies and regulations. Technology changes include use of borate preservatives to dual-treat wood ties to provide longer service life in high decay environments, non-wood ties made of concrete or plastic, and energy conversion methods for used ties such as gasification and torrefaction. Passage of the EPA Non-Hazardous Secondary Materials (NHSM) rule in 2011, including updates in 2013,2016, and 2018, is reducing the potential for recycling used ties as fuel. However, the EPA is also promoting use of biological materials, such as wood, to produce energy without increasing carbon dioxide $\left(\mathrm{CO}_{2}\right)$ levels in the atmosphere, thus reducing human caused climate change. Purchase and tie management trends are indicated by the survey results. Approximately $95 \%$ of all ties purchased are preservative-treated wood. Due to demonstrated longer service life in high decay zones for wood ties that are dual treated with borate and either creosote or copper naphthenate, the fraction of concrete and plastic tie purchases has decreased while the faction of dual treated wood tie purchases has increased. Recycling used ties for energy remains the most common practice, at $66 \%$ of ties, but has declined from $81 \%$ in 2013. Reuse of ties for other treated wood uses, such as landscape and agricultural type purposes, remains common at approximately $18 \%$. Landfill disposal remains uncommon, but seems to be increasing at $6 \%$ of removed
\end{abstract}

*Stephen Smith is a Professional Engineer with over 35 years of experience in the wood preserving industry. This includes 20 years with a major wood preserving company and over 15 years consulting to various organizations in the industry, including a series of Environmental Life Cycle Assessments for the Treated Wood Council. 
ties. The shift away from recycling for energy is thought to result from the both impact of the EPA NHSM rule and the low cost of natural gas. The smaller market tie users, mainly the short line railroads in contrast to the Class 1 railroads, manage far fewer ties per company, but purchase and manage approximately $31 \%$ of all ties. The short lines recycle to landscape and agricultural uses at about half the rate of the Class 1s and dispose in landfills at a much higher rate of $76 \%$ versus $1.2 \%$ for the Class $1 \mathrm{~s}$. This difference is thought to result from the economics and availability of local versus distant management options.

\section{Keywords}

Creosote, Copper Naphthenate, Borate, Railroad Ties, Crossties

\section{Introduction}

With approximately 207,000 miles of occupied track in the United States [1] and supporting crossties of approximately 3000 per mile, railroads have approximately 620 million crossties currently in use in the U. S. Ties wear-out through normal decay, insect attack, and physical impact and abrasion and as the result of derailments, rail modifications, or other causes. Approximately 23 million new wood ties are purchased and installed in the North American rail network every year [2].

Most new ties are installed to replace old ties. The ties taken out of service, such as shown in Figure 1, require management by the railroads. Potential means of management include recycling for lighter duty use as ties in a railroad, reuse for landscaping or agricultural purposes, reuse as fuel, disposal via landfills or incineration, or storage pending one of the above options.

Due to potential environmental impacts or human risks associated with such management options, regulatory agencies have stated concerns about how used ties are managed. In addition, information regarding the types of railroad ties being put into service and the methods of management of ties following use is important to the railroad and wood preserving industries and the government bodies for various other reasons. In response to questions posed by the U. S. Environmental Protection Agency (EPA), the Railway Tie Association (RTA) conducted a survey and provided results to the EPA about tie management in 2008. In response to further regulatory attention and passage of Non-Hazardous Secondary Materials Rule, the survey was expanded and repeated in 2014.

Regulatory pressure continues while the potential to use ties as fuel seems to be declining in the face of increased regulation and competition from low cost natural gas. Passage of the EPA Non-Hazardous Secondary Materials (NHSM) rule in 2011, including updates in 2013, 2016, and 2018, [3] is reducing the potential for recycling used ties as fuel. Further, railroads desire to be better able to describe their operations as renewable and good for both the environment and 


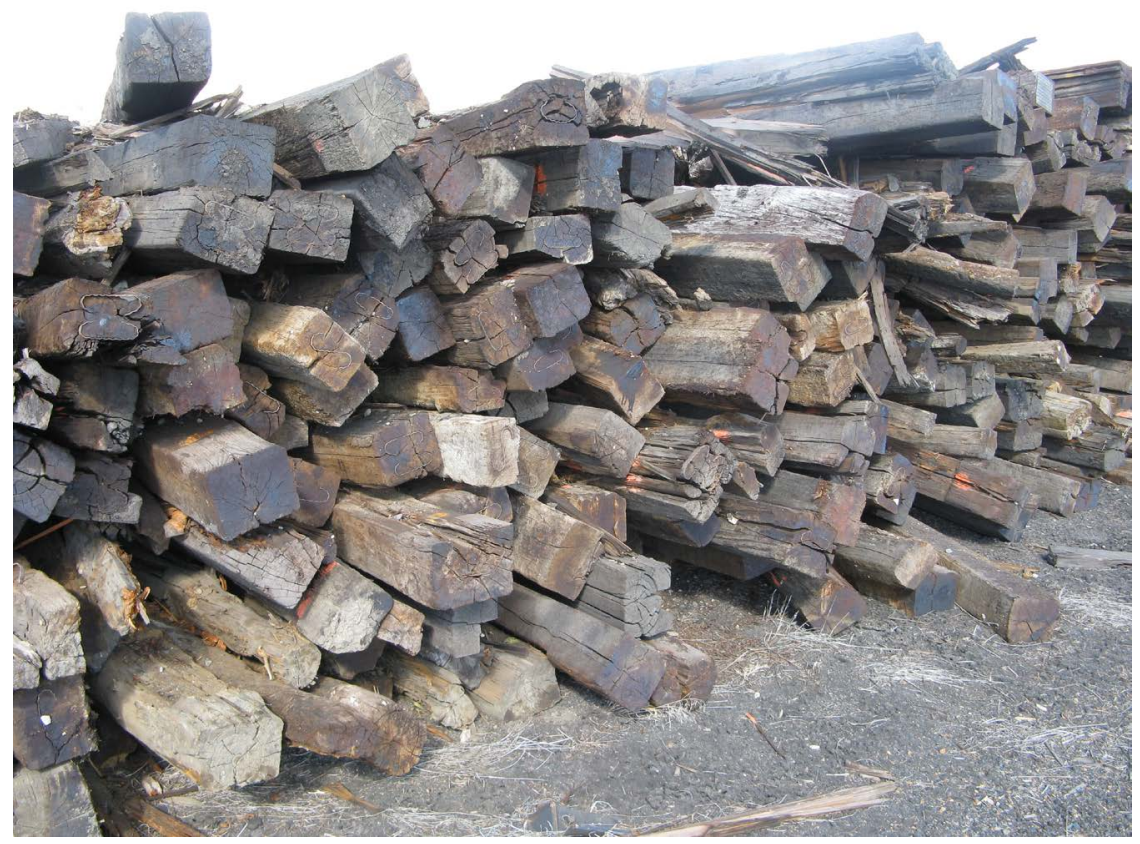

Figure 1. Used ties awaiting further management (Photo by author).

the economy. This effort could be supported by the EPA, which is also promoting use of biological materials, such as wood, to produce energy without increasing carbon dioxide $\left(\mathrm{CO}_{2}\right)$ levels in the atmosphere, thereby reducing human caused climate change [4]. EPA is mandated to continue reviewing all wood preservatives in their ongoing process required under the Federal Insecticide, Fungicide, and Rodenticide Act (FIFRA), which could have future impacts on crosstie use by the railroads. Storage of used ties also causes concern [5].

In the face of changing conditions and ongoing regulatory interest, the Association of American Railroads (AAR) decided it was important to conduct a new survey to provide more complete and up-to-date information about tie purchases and management by the railroads. The AAR sent survey questionnaires to Class 1 and short line railroads and Amtrak in late 2018 and early 2019 for tie purchase and management information for calendar year 2017. This report covers the results of that survey.

\section{Background}

In late 2018, the AAR contracted with Stephen Smith, P.E. to conduct a new survey of railroads' tie purchase and management practices. The survey questionnaire, modified only slightly from the one used for the 2014 survey, was sent to Class 1 railroads in late 2018. The survey was expanded in early 2019 with the help of the American Short Line and Regional Railroad Association (ASLRRA) and the Railway Tie Association (RTA), with the survey being sent to approximately 70 short line railroads.

The survey questionnaire was designed in two parts. The first part was intended to be completed by railroad companies. This asked for the 2017 annual 
number of ties purchased and the percentages of ties of typical types; creosote, creosote/borate, copper naphthenate, copper naphthenate/borate, water-borne, concrete, steel, or plastic composite. It also asked for the number of ties removed in 2017. If these were handled by contractors, the names of contractors were requested and the railroad was asked to forward the questionnaire to these contractors to be completed. If these were handled by the railroad, the percentage of ties was requested for each fate; reuse by same or another railroad, reuse for commercial or residential landscaping, reuse for farms or agriculture, recycle for energy by combustion or gasification, disposal by incineration or landfill, or other. The second part was intended to be completed by contractors that manage ties for a railroad and included the same options as above.

Responses were received from all seven Class 1 railroads, Amtrak, and nine short line railroads. 14 responses from contractors were received. Since each contractor response was for one railroad's business, one contractor could have multiple responses covering different railroad customers.

\section{Ties Survey Results}

A total of 31 completed responses (including one that was text in an email) were received. These covered all seven Class 1 railroads, nine short line railroads, Amtrak, and 14 contractor responses that covered railroads that did not report their own management. This was a substantial increase over the 2014 survey that had 13 responses. A total of 15.1 million tie purchases were reported for 2017. This compares to approximately 20.0 million tie purchases reported by RTA for all U.S. railroads in 2017 [6] and approximately 24 million ties for all U.S. tie purchasers $[7]^{1}$. Thus, results of this survey indicate that responding railroads reported approximately $63 \%$ to $76 \%$ of U.S. tie purchases. By class, $100 \%$ of Class 1 s and approximately $16 \%$ to $32 \%$ of short line and other small market tie purchases were reported ${ }^{2}$.

\subsection{Types of Ties Being Purchased}

A total of approximately 15.1 million ties were reported purchased in 2017 by the survey respondents. The percentages and numbers of each type of tie purchased are summarized in Table 1. Importantly, 94.8\% of all ties purchased were preserved wood.

In addition to the types of ties purchased, railroads were asked if potential for using the ties as fuel at the end of the use life was an important consideration regarding the purchase choice. Five railroads responded yes and 13 either responded no or did not respond to this question. The five "yes" responders represent $85 \%$ of the tie purchases reported.

${ }^{1}$ Note that all U.S. tie purchasers includes small market, which includes short lines, contractors, transit agencies, industrial sites, and others. The small market purchases were reported in Table 2 of Crossties, May/June 2018.

${ }^{2}$ Larger fraction is amount in survey relative to amount in Crossties Sep./Oct. 2018 and smaller fraction is relative to small market estimate of ties in Crossties May/June 2018, 10-12. 
Table 1. Tie purchases.

\begin{tabular}{ccccccccc}
\hline \multicolumn{1}{c}{ Percentage and Number of Each Type } \\
\hline Creosote & Creosote-borate & Copper naph & CuNap-Borate & Water borne & Concrete & Steel & Plastic \\
\hline $49.0 \%$ & $44.2 \%$ & $0.1 \%$ & $1.5 \%$ & $0.0 \%$ & $4.6 \%$ & $0.3 \%$ & $0.3 \%$ \\
$7,401,043$ & $6,670,953$ & 8,150 & 220,000 & 0 & 698,350 & 47,260 & 48,333 \\
\hline
\end{tabular}

\subsection{Used Tie Management}

Survey results covered the management of approximately 16.5 million ties in 2017. The percentages and numbers for each type of management are summarized in Table 2.

Information regarding the cost of recycling ties for energy or disposing in landfills was also requested. Only four railroads reported for energy recycling ( $8 \%$ of ties to energy) and eight for landfill (78\% of landfilled ties) costs. For those that did report a tipping fee for recycling for energy, the fee was approximately $\$ 20 /$ ton. Landfill disposal was reported for a small fraction of ties, but by more railroads. Landfill tipping fees ranged widely from $\$ 26$ to $\$ 104 /$ ton with a weighted average for reported fees of approximately $\$ 40 /$ ton. It should be noted that the tipping fees do not include handling (loading, unloading, and grinding) and transportation to the recycling facility or landfill. Those costs can be substantial.

\subsection{Comparison to 2014 and 2008 Surveys}

Trends in tie purchasing are not dramatic, but subtle changes can be seen. The total percentage of creosote and creosote/borate increased from 89\% in 2013 to $93 \%$ in 2017. A corresponding decrease in non-wood ties (concrete, steel, and plastic) from $9 \%$ in 2013 to 5\% in 2017 occurred. Copper naphthenate and copper naphthenate/borate dual treatment remained small at less than $2 \%$, while water borne preservative treatments remained at $0 \%$.

As noted above, the RTA completed surveys of tie management in 2008 and 2013. Results of those surveys are included in Table 3.

While the current results are generally similar to those from 2014 and 2008, there are some differences that may be important. Table 4 summarizes management methods and highlights the differences. The results indicate significant changing trends in practices. Reuse by railroads remains a fairly small fraction, probably because few removed ties are really suitable to be reinstalled. Landscape uses declined from 2008 to 2013 and then increased by 2017. These changes were mostly reflected in opposite trend changes in recycle for energy uses, which increased from 2008 to 2013 and then declined by 2017. Landfill disposal seems to have declined from 2008 to 2013 and then increased by 2017 . The likely explanation for the increase number of ties to landfills is a reduction in the number of facilities accepting used ties due to the NHSM rulemaking which allows creosote treated ties to only be burned in boilers either capable of 
Table 2. Tie management.

\begin{tabular}{cccccccccc}
\hline \multicolumn{7}{c}{ Percentage and Number of Ties by Each Management Method } \\
\hline $\begin{array}{c}\text { Reuse by } \\
\text { same RR }\end{array}$ & $\begin{array}{c}\text { Reuse by } \\
\text { other RR }\end{array}$ & $\begin{array}{c}\text { Reuse } \\
\text { commercial } \\
\text { landscape }\end{array}$ & $\begin{array}{c}\text { Reuse } \\
\text { agriculture }\end{array}$ & $\begin{array}{c}\text { Reuse residential } \\
\text { land-scape }\end{array}$ & Other & Incineration & $\begin{array}{c}\text { Recycle } \\
\text { combustion } \\
\text { (for energy) }\end{array}$ & $\begin{array}{c}\text { Recycle } \\
\text { gasify } \\
\text { (for energy) }\end{array}$ & $\begin{array}{c}\text { Landfill } \\
1.0 \%\end{array}$ \\
\hline $1.1 \%$ & $12.5 \%$ & $4.1 \%$ & $10.4 \%$ & $0.0 \%$ & $0.0 \%$ & $65.7 \%$ & $0.2 \%$ & $6.0 \%$ \\
\hline 172,824 & 16,451 & $2,063,437$ & 669,899 & $1,727,078$ & 0 & 0 & $10,862,420$ & 24,866 & 995,938 \\
\hline
\end{tabular}

Table 3. Comparisons between 2008, 2013, and 2017 surveys.

\begin{tabular}{|c|c|c|c|c|c|c|c|c|c|c|c|}
\hline \multicolumn{12}{|c|}{ Number and Percentage of Ties by Each Management Method by Survey Year } \\
\hline \multicolumn{12}{|c|}{2017 Survey Results } \\
\hline Description & Total ties & $\begin{array}{c}\text { Reuse } \\
\text { by same }\end{array}$ & $\begin{array}{l}\text { Reuse by } \\
\text { other RR }\end{array}$ & $\begin{array}{c}\text { Reuse } \\
\text { commercial } \\
\text { landscape }\end{array}$ & $\begin{array}{c}\text { Reuse } \\
\text { agriculture }\end{array}$ & $\begin{array}{c}\text { Reuse } \\
\text { residential } \\
\text { landscape }\end{array}$ & Other & Incineration & $\begin{array}{c}\text { Recycle } \\
\text { combustion } \\
\text { (for energy) }\end{array}$ & $\begin{array}{c}\text { Recycle } \\
\text { gasify } \\
\text { (for energy) }\end{array}$ & Landfill \\
\hline $\begin{array}{l}\text { Number } \\
\text { of ties }\end{array}$ & $16,532,913$ & 172,824 & 16,451 & $2,063,437$ & 669,899 & $1,727,078$ & 0 & 0 & $10,862,420$ & 24,866 & 995,938 \\
\hline $\begin{array}{c}\text { Percent } \\
\text { of ties }\end{array}$ & & $1.0 \%$ & $0.1 \%$ & $12.5 \%$ & $4.1 \%$ & $10.4 \%$ & $0.0 \%$ & $0.0 \%$ & $65.7 \%$ & $0.2 \%$ & $6.0 \%$ \\
\hline \multicolumn{12}{|c|}{2014 Survey Results } \\
\hline $\begin{array}{l}\text { Number } \\
\text { of ties }\end{array}$ & $12,236,059$ & 95,205 & 12,573 & $1,406,322$ & 50,292 & 689,190 & 0 & 0 & $9,949,049$ & 0 & 33,429 \\
\hline $\begin{array}{c}\text { Percent } \\
\text { of ties }\end{array}$ & & $0.8 \%$ & $0.1 \%$ & $11.5 \%$ & $0.4 \%$ & $5.6 \%$ & $0.0 \%$ & $0.0 \%$ & $81.3 \%$ & $0.0 \%$ & $0.3 \%$ \\
\hline \multicolumn{12}{|c|}{2008 Survey Results } \\
\hline $\begin{array}{c}\text { Number } \\
\text { of ties }\end{array}$ & $17,100,332$ & 802,975 & & $2,462,402$ & 883,750 & $2,455,500$ & & & $9,195,500$ & 425,000 & 875,205 \\
\hline $\begin{array}{l}\text { Percent } \\
\text { of ties }\end{array}$ & & $4.7 \%$ & & $14.4 \%$ & $5.2 \%$ & $14.4 \%$ & & & $53.8 \%$ & $2.5 \%$ & $5.1 \%$ \\
\hline
\end{tabular}

Table 4. Survey result comparisons.

\begin{tabular}{|c|c|c|c|c|}
\hline Report Years & RR Reuse & Landscape type uses & Energy uses & Landfill \\
\hline \multirow{2}{*}{2017 data } & $1.1 \%$ & $27 \%$ & $65.9 \%$ & $6.0 \%$ \\
\hline & 189,275 & $4,460,414$ & $10,887,286$ & 995,938 \\
\hline \multirow{2}{*}{2013 data } & $0.9 \%$ & $18 \%$ & $81.3 \%$ & $0.3 \%$ \\
\hline & 107,778 & $2,145,804$ & $9,949,049$ & 33,429 \\
\hline \multirow{2}{*}{2008 data } & $4.7 \%$ & $34 \%$ & $56.3 \%$ & $5.1 \%$ \\
\hline & 802,975 & $5,801,652$ & $9,620,500$ & 875,205 \\
\hline Change from 2013 to 2017 & $30 \%$ & $54 \%$ & $-19 \%$ & $2105 \%$ \\
\hline Change from 2008 to 2013 & $-81 \%$ & $-48 \%$ & $44 \%$ & $-95 \%$ \\
\hline Change from 2008 to 2017 & $-76 \%$ & $-21 \%$ & $17 \%$ & $18 \%$ \\
\hline
\end{tabular}


burning or were previously capable of burning fuel oil and low natural gas prices that lowers the value used ties as fuel. Another possible explanation could be differences in reporting by the short line railroads.

It is likely that the changes in management results from 2008 to 2013 to 2017 do reflect changes in industry practice. However, since the results are mostly reflective of the Class 1 railroads, practices by the short line, regional, and commuter railroads may be significantly different.

\subsection{Short Line and Regional Railroads}

While this survey succeeded in getting nine short line railroads to participate, their combined management quantity of ties was only $9 \%$ of the total. Since the small market tie users, including Short Line and Regional railroads, account for approximately $31 \%$ of tie purchases ${ }^{3}$, their practices could be substantially different than indicated in this survey. These differences seem significant and are likely due to the different conditions in which the smaller railroads operate.

As shown in Table 5, short line railroads and Amtrak reuse ties for landscape and agricultural purposes at approximately half the rate of Class $1 \mathrm{~s}$. They dispose of ties in landfills at over 60 times higher rates (76\% versus 1.2\%). This higher landfill disposal by short lines is countered by much lower recycling for energy (combustion and gasification) that is about one-sixth the rate of Class 1s. These differences seem likely the result of the short lines' lack of access to more distant, and thus more expensive, transport to cogeneration facilities. With less ability to use and the higher cost of combustion facilities permitted to use ties, the short lines seem to have resorted to landfill disposal. Landfill disposal is thus a higher cost necessity. The higher use of gasification by short lines implies that they are trying to make use of energy recycling methods other than combustion. Any regulations that would further restrict reuse of ties for landscaping or agricultural uses would likely impact the short line railroads more severely than the Class $1 \mathrm{s.}$

As noted, only a small number of the more than 500 short line railroads responded. Tie purchases reported by short lines and Amtrak totaled approximately 1,294,000. However, the "small market", consisting generally of all tie uses except the Class 1s, is estimated to be 7,903,000 ties in 2017 [8]. A less inclusive survey of short line railroads reported total tie purchases at 2.1 million with about $52 \%$ representation of track miles, implying total short line purchases of approximately 4.0 million ties. Since the small market railroads dispose of ties

Table 5. Comparison of class 1 and short line RRs.

\begin{tabular}{|c|c|c|c|c|c|c|c|}
\hline RR Type & Number ties & $\begin{array}{c}\text { Reuse commercial } \\
\text { landscape }\end{array}$ & $\begin{array}{c}\text { Reuse } \\
\text { agriculture }\end{array}$ & $\begin{array}{c}\text { Reuse residential } \\
\text { landscape }\end{array}$ & $\begin{array}{l}\text { Recycle combustion } \\
\text { (for energy) }\end{array}$ & $\begin{array}{l}\text { Recycle gasify } \\
\text { (for energy) }\end{array}$ & Landfill \\
\hline Class 1s Total & $15,476,705$ & $12.9 \%$ & $3.9 \%$ & $11.1 \%$ & $69.6 \%$ & $0.0 \%$ & $1.2 \%$ \\
\hline SL \& Amtrak & $1,056,208$ & $5.8 \%$ & $6.1 \%$ & $0.5 \%$ & $8.6 \%$ & $2.4 \%$ & $76.2 \%$ \\
\hline
\end{tabular}

${ }^{3}$ Calculated as average for years 2014-2018 from values in Table 1 of Crossties Jan./Feb. 2018, 12. 
in landfills at much higher rates than Class 1 s, the total reported landfill quantity of approximately 1 million ties (Table 4 ) is probably misleading. Accounting for the small market size and high landfill disposal proportion, the likely landfill total is approximately 6 million ties $(7,903,000 / 1,294,000) \times 995,938)$.

\section{Discussion}

All railroads seek to manage their worn ties in ways that minimize cost and long-term liability. Often, railroads have contractors pick up all ties from a project or simply complete the whole project such that the contractor makes decisions about used tie management. The contractor seeks to maximize value, or at least minimize cost, by sorting ties by quality and potential for other uses. Better quality ties are sorted to be marketed for landscape or agricultural uses and may be sold to middlemen or retail building supply companies. Some railroads do not allow used ties to be used for agricultural, commercial, or residential reuse due to the long-term liability. Ties unsuitable for reuse will generally be used as fuel for energy recovery or process heat boilers. Processing of such ties into fuel involves metal removal and grinding. Processing may be completed by the same contractor or may involve transfer to another company that grinds and markets the fuel to end users. Processing ties can be expensive and may require a tipping fee for ties accepted. Railroads or contractors that cannot cost effectively utilize the fuel alternative generally must dispose of remaining ties in landfills, for which a tipping fee will be required.

The result of this contractor management scenario is that the railroad companies are insulated from the actual cost of managing low quality used ties because the value of the better quality used ties can balance, or at least reduce, the overall management cost.

The lack of information about specific tipping fees for energy use and landfill disposal is reflected in the survey responses. Survey responses for only 0.8 million of the 10.8 million ties recycled for energy reported tipping fees. Of nearly one million ties disposed in landfills, the tipping fee was reported for approximately three-quarters of ties, but nearly all disposal was reported by only one responder. Thus, the survey responses do not provide reliable information about costs to railroads for various used tie management options.

In order to obtain better information, a large contractor familiar with costs to manage ties was confidentially contacted [9]. The contractor indicated that, though quite variable, typical costs for handling, transportation, and disposal in landfills is about $\$ 120 /$ ton, including the tipping fee of about $\$ 50 /$ ton. These values are considered more representative of the overall railroad industry than the limited survey responses.

The Class 1 railroads are particularly well suited to obtain low pricing for recycling to energy with their consistent, large quantity supply of used ties, large, nearly continental, scope of rail networks, and ability to use dedicated rail cars for used tie transport. This, coupled with contractors that maximize the value of 
better-quality ties removed with lower quality ties, results in efficient and lower overall management cost of used ties. Due to this efficiency and scale, actual costs to Class 1 railroads for management of used ties that are recycled for energy is not known, but is roughly estimated to be approximately half the cost of landfill disposal as described above. That would consist of approximately \$35/ton for transportation, handling, and grinding and \$25/ton tipping fee for energy use by combustion ${ }^{4} ; \$ 60 /$ ton less than landfill disposal.

Regulatory action by EPA to either further restrict or encourage recycling of used ties to energy will have impacts. For example:

- If restrictions on reuse caused half of the landscape and agricultural use ties to be landfilled, the annual increased cost to the industry would be approximately $\$ 120$ million (2,200,000 ties/13 ties/ton $\mathrm{x} \$ 120 /$ ton $)$.

- If restrictions on recycling for energy caused half of the ties managed for energy to be disposed in landfills, the added annual cost (primarily to Class 1 railroads) would be $\$ 25$ million (5,400,000 ties/13 ties/ton $\times \$ 60 /$ ton) .

- If restrictions on recycling for energy were eased, facilities accepting and demand for used ties would increase, allowing more ties to be recycled for energy instead of landfill disposal. If half of the ties now disposed in landfills were recycled for energy, annual savings of $\$ 2.3$ million (500,000 ties/13 ties/ton $\times \$ 60 /$ ton) could result.

- Greenhouse gas emissions would be reduced if more used ties, biogenic, renewable fuel, replace use of fossil fuels for energy [10].

Various benefits accrue to society as a result of railroads ability to recycle used ties for other uses and energy:

- Ties used for landscaping and agricultural purposes provide long term service at low cost to the end users. Further, EPA noted that such uses pose very little exposure potential so EPA "will not conduct a residential post-application risk assessment" [11].

- Landfills will last longer if space is not used for disposed ties.

- Lower levels of GHG will exist in the environment due to use of ties as renewable fuel that offset fossil fuel combustion.

- Forests are maintained, tax bases improved, and well-paying jobs result as domestic wooden ties are produced, used, and recycled by railroads.

\section{Conclusions}

Current practice for new tie purchases remains largely as it has been for decades with the largest fraction (49\%) of ties being preserved by creosote treatment. Added to this is an increasing trend, currently at $46 \%$ of purchases, to dual treat with borate and creosote. Dual treated ties with borate and copper naphthenate, a relatively new preservative system for the railroad market, have maintained a small share of nearly $2 \%$ of purchases. Nearly $95 \%$ of all ties purchased are preserved wood. Concrete ties, at about $5 \%$ and steel ties at about $0.3 \%$, have been

${ }^{4}$ This differs from the limited survey results indicating fees of $\$ 20 /$ ton for energy recycling and $\$ 40 /$ ton for landfill disposal. 
present in the tie market for at least a couple decades, but seem to retain diminishing market share by fitting particular market niches.

The most utilized management technique for used ties is recycling for energy via combustion at approximately $66 \%$ of all removed ties, although this is down significantly from $81 \%$ four years earlier. Recycling ties to other uses appropriate for preserved wood, such as use in landscaping or agricultural functions, are common with approximately $18 \%$ of ties removed. Disposing used ties in landfills is uncommon, but increasing, at $6 \%$ of ties overall, but is much more common for short line railroads at $76 \%$.

Cost data was not reported by many responders, so is not complete. However, based on those that did report costs, the fee for recycling for energy via combustion is approximately $\$ 20 /$ ton (about $\$ 1.50 /$ tie) and for landfill disposal $\$ 40 /$ ton (about $\$ 3 /$ tie). Note that these values are based on a small response rate, are highly variable, and do not include other handling and transportation costs.

Relative to the Class 1 railroads, short lines dispose of many more ties in landfills and recycle fewer to energy use.

Purchase trends in this current survey compared to the 2013 results are most notable in that use of wood ties over non-wood ties seems to be increasing and that borate dual treatment has increased substantially. The borate treatments will likely result in longer average service life of the ties. These trends seem to logically reflect improved performance of borate dual treated ties in the southeastern U.S. that are less costly than the non-wood ties ${ }^{5}$.

Management trends are interesting in that the trend directions from 2008 to 2013 reversed for 2013 to 2017. Landscape and agricultural reuse and landfill disposal first decreased and then increased for the current survey. Fuel uses (combustion and gasification) increased and then decreased. Recent management trends seem likely driven by regulation changes, particularly EPA's NHSM Rule.

Changes to EPA regulations that further restrict or encourage recycling used ties for energy will affect U.S. railroads economics and used tie management practices and fossil fuel-related greenhouse gas emissions.

\section{Funded}

This work is jointly funded by the Association of American Railroads and the Railway Tie Association.

\section{Conflicts of Interest}

The author declares no conflicts of interest regarding the publication of this paper.

\section{References}

[1] Crossties (2018) Survey Says? The World Is Flat for Tie Demand (... at the Moment). 10-13.

${ }^{5}$ The trend of increasing use of dual treated ties continued in 2018 according to some purchasers. 
[2] Crossties (2018) Will Annual GDP Growth Break the 3\% Mark? 10-12.

[3] EPA Identification of Non-Hazardous Secondary Materials That Are Solid Waste. https://www.epa.gov/rcra/identification-non-hazardous-secondary-materials-are-so lid-waste

[4] EPA Carbon Dioxide Emissions Associated with Bioenergy and Other Biogenic Sources.

https://19january2017snapshot.epa.gov/climatechange/carbon-dioxide-emissions-as sociated-bioenergy-and-other-biogenic-sources_html

[5] Cargouët, M., Jeannee, N., Vidart, B. and Gregori, P. (2018) Polycyclic Aromatic Hydrocarbon (PAH) Levels in Environmental Media Potentially Impacted by Reused or Stored Creosote-Treated Railway Ties. Environmental Science and Pollution Research, 25, 17409-17424. https://doi.org/10.1007/s11356-018-1910-9

[6] Crossties, Sept./Oct. 2018.

[7] Crossties May/June 2018.

[8] Crossties, May/June 2018, 10-12.

[9] Gauntt, J. (2019) Confidential Communication by Railway Tie Association.

[10] Bolin, C. and Smith, S. (2013) Life Cycle Assessment of Creosote-Treated Wooden Railroad Crossties in the US with Comparisons to Concrete and Plastic Composite Railroad Crossties. Journal of Transportation Technologies, 3, 149-161. https://doi.org/10.4236/jtts.2013.32015

[11] Environmental Protection Agency, Creosote Preliminary Work Plan (2015) Registration Review: Initial Docket Case Number 0139. EPA Docket No. EPA-HQ-OPP-2014-0823. 